OPEN ACCESS

Edited by:

Sarah Maylin,

Assistance Publique-Hôpitaux De

Paris, France

Reviewed by:

Jorge Quarleri,

Consejo Nacional de Investigaciones

Cientificas y Técnicas (CONICET),

Argentina

Xiaohui Zhou,

Fudan University, China Yean Kong Yong,

Xiamen University Malaysia, Malaysia

${ }^{*}$ Correspondence:

Soma Banerjee

somabanerjee70@gmail.com

Specialty section:

This article was submitted to

Virology,

a section of the journal

Frontiers in Microbiology

Received: 09 March 2021

Accepted: 06 July 2021

Published: 30 August 2021

Citation:

Ghosh S, Chakraborty A and

Banerjee S (2021) Persistence

of Hepatitis $B$ Virus Infection:

A Multi-Faceted Player

for Hepatocarcinogenesis.

Front. Microbiol. 12:678537.

doi: 10.3389/fmicb.2021.678537

\section{Persistence of Hepatitis B Virus Infection: A Multi-Faceted Player for Hepatocarcinogenesis}

\author{
Suchandrima Ghosh, Anannya Chakraborty and Soma Banerjee* \\ Centre for Liver Research, School of Digestive and Liver Diseases, Institute of Post Graduate Medical Education \\ and Research, Kolkata, India
}

Hepatitis B virus (HBV) infection has a multi-dimensional effect on the host, which not only alters the dynamics of immune response but also persists in the hepatocytes to predispose oncogenic factors. The virus exists in multiple forms of which the nuclear localized covalently closed circular DNA (cccDNA) is the most stable and the primary reason for viral persistence even after clearance of surface antigen and viral DNA. The second reason is the existence of pregenomic RNA (pgRNA) containing virion particles. On the other hand, the integration of the viral genome in the host chromosome also leads to persistent production of viral proteins along with the chromosomal instabilities. The interferon treatment or administration of nucleot(s)ide analogs leads to reduction in the viral DNA load, but the pgRNA and surface antigen clearance are a slow process and complete loss of serological HBsAg is rare. The prolonged exposure of immune cells to the viral antigens, particularly HBs antigen, in the blood circulation results in T-cell exhaustion, which disrupts immune clearance of the virus and virus-infected cells. In addition, it predisposes immune-tolerant microenvironment, which facilitates the tumor progression. Thus cccDNA, pgRNA, and HBsAg along with the viral DNA could be the therapeutic targets in the early disease stages that may improve the quality of life of chronic hepatitis B patients by impeding the progression of the disease toward hepatocellular carcinoma.

Keywords: hepatitis B Virus, HBV, HBV persistence, hepatocellular carcinoma, HCC

\section{INTRODUCTION}

Despite being a vaccine-preventable viral infection, hepatitis B virus (HBV) infection is a major global health problem. It is transmitted through perinatal, percutaneous, and sexual exposures. This virus replicates in the hepatocytes of the liver, and in $90 \%$ of adults, it manifests self-limiting acute infection with the elimination of the viral DNA and development of anti-core antibody, and seroconversion of HBe-antigen and HBs-antigen (Liang, 2009). In contrast, persistence of HBs-antigen for more than 6 months in adults or perinatal transmission in case of newborn babies in the absence of immunoprophylaxis develops chronic infection (Trehanpati et al., 2013). The natural history of 
chronic hepatitis $\mathrm{B}(\mathrm{CHB})$ phases comprise (1) $\mathrm{HBe}^{-\mathrm{Ag}^{+}}$phase that includes immune tolerant phase (no hepatitis), and immune active, or immune clearance phase (active hepatitis phase), and (2) anti- $\mathrm{HBe}^{+} / \mathrm{HBe}-\mathrm{Ag}^{-}$phase including inactive carrier (minimum or no hepatitis) and reactivation $\left(\mathrm{HBe}-\mathrm{Ag}^{-}\right.$active hepatitis) (Figure 1). Thus, $\mathrm{CHB}$ (both $\mathrm{HBeAg}^{+}$and $\mathrm{HBeAg}^{-}$) often causes life-threatening end-stage liver diseases such as liver cirrhosis (LC) and hepatocellular carcinoma (HCC). Although the infection rate has dropped in children under 5 years of age to $1 \%$ because of the global vaccination program, a WHO report suggests that the estimated number of HBV chronic carriers is about 257 million. The most astonishing data is that as of 2015, deaths from this virus mainly related to LC and HCC and it almost reached 8.8 million (WHO, 2020).

The uniqueness in $\mathrm{HBV}$ genome organization and its complex life cycle have a multi-dimensional effect on the virushost interaction, and its persistence leads to predisposition of oncogenic factors. Multiple aspects in $\mathrm{HBV}$ infection are related to both viral persistence and disease progression such as (1) the complex life cycle of this partially double-stranded DNA virus mediated through myriads of RNA intermediates and its presence as virion particles, (2) viral genome encoded transactivator proteins and their gene regulatory functions in a multifunctional way, (3) integration of the virus genome into the host chromosome causing genome instabilities, (4) accumulation of immune escape mutations in antigenic viral proteins, and (5) virus-host interaction to suppress immune response (Hai et al., 2014; Tan et al., 2015; Hu et al., 2019; Lazarevic et al., 2019). In addition, nucleotide sequence variations in the viral genome itself dissect drug sensitivity of different viral genotypes and subgenotypes. In this review, the perspectives of viral persistence and the disease progression toward HCC have been delineated, particularly HBV RNA intermediates, drugresistant covalently closed circular DNA (cccDNA), contribution of genotype/subgenotype and mutations, constitutive presence of viral surface and $\mathrm{HBx} / \mathrm{N}$-terminally truncated $\mathrm{HBx}$ protein from integrated viral DNA, and defective immune responses, to identify the current lacunae which need more light of research.

\section{LIFE CYCLE OF HBV THROUGH RNA INTERMEDIATES: A KEY TO DISEASE PATHOGENESIS}

\section{HBV RNAs and Its Origin}

Hepatitis B virus is the smallest enveloped partially doublestranded or relaxed circular DNA (rcDNA) virus with genome length of $3.2 \mathrm{~kb}$ belonging to the Hepadnaviridae family. Its genome encompasses four open reading frames (ORFs) with overlapped sequences: pre-C/C (pre-core/core), pre-S/S (surface proteins), $\mathrm{X}$ (transcriptional co-activator), and P (DNA polymerase) (Figure 1). During infection, the virus particles enter into the cytoplasm of the hepatocyte through a noncovalent attachment of the 77aa of the viral surface protein to the glycosaminoglycans such as heparin sulfate followed by internalization through a highly specific binding to the sodium taurocholate co-transporting polypeptide (NTCP) receptor, and decoates the genome (Le Seyec et al., 1998, 1999; Meier and Stieger, 2002; Yan et al., 2012; Somiya et al., 2016). The rcDNA converts into covalently closed circular DNA (cccDNA) using host repair enzymes in the nucleus (Koniger et al., 2014; Cui et al., 2015; Qi et al., 2016; Long et al., 2017; Kitamura et al., 2018; Tang et al., 2019; Xia and Guo, 2020). This cccDNA acts as a template for all the HBV RNAs. Recent studies have showed that the diversified distribution of the transcription start sites (TSSs) in the HBV genome along with their differential engagement with the transcription factors and RNA polymerase result in heterogeneity in the viral RNA pool (Altinel et al., 2016). Canonically, two different TSSs of the core promoter generate two different 3.5-kb transcripts, one having the start codon for pre-core (preC) and the other originating $4 \mathrm{bp}$ downstream of pre-core start codon generating pgRNA. Recently, splice variant of pgRNA has been also reported in CHB patients (Chen et al., 2015; Duriez et al., 2017). A similar heterogeneity is observed in the transcription of surface proteins: (1) preS1 promoter encodes for large protein (LHBs of 389aa/400aa) and (2) preS/S promoters located within the preS1 gene give rise to middle (MHBs of 281aa) and small (SHBs of 226aa) surface proteins, respectively. Despite predominance of the promoter activity of preS/S, TSS usage determines the ratio of $\mathrm{MHBs}$ and SHBs. Lastly, $0.7 \mathrm{~kb}$ $\mathrm{X}$ mRNA encodes HBx protein and an N-terminally truncated $\mathrm{HBx}$ protein, the origin of which is the alternate TSS located in between the first and second codons of HBx (Will et al., 1987; Yaginuma et al., 1993; Quarleri, 2014; Altinel et al., 2016).

The uniqueness of pgRNA is that it is not only used as template for translation of viral polymerase $(\mathrm{P})$ and core protein, it is reverse transcribed into viral DNA after packaging in viral capsid with a single unit of polymerase protein and rcDNA is produced within the capsid (Nassal, 1992, 2008; Weber et al., 1994; Jeong et al., 2000). This newly synthesized viral capsid can reinfect the nucleus to replenish the cccDNA pool and the remaining capsids are enveloped in endoplasmic reticulum and then secreted through Golgi bodies in the blood as infectious Dane particle. Thus, pgRNA, spliced pgRNAs, preS2/PreS1/S RNA, and HBx RNA could be the major factors for disease progression toward HCC. Woodchuck hepatitis model with Woodchuck hepatitis virus (WHV) also revealed similar causal factors for liver disease progression (Mason et al., 2005).

\section{Impact of HBV RNAs on Persistence of CHB}

A few recent evidences suggest that intrahepatic and circulatory pgRNAs could be the predictor for the transcriptional activity of the cccDNA in HBV-positive hepatocytes and the level of pgRNA correlates with the natural course of HBV infection (Wang et al., 2018a,b; Lin et al., 2020). For example, pgRNA level is higher in $\mathrm{HBe}^{+}$compared with $\mathrm{HBe}^{-}$patients, and it is lowest in inactive carriers (Liu Y. et al., 2019). Again in treatment naive patients serum HBV RNA or pgRNA correlates well with both intrahepatic cccDNA as well as with serum HBV DNA and HBsAg level. Such correlation between serum HBV RNA, serum HBV DNA and HBsAg is also detectable after treatment 


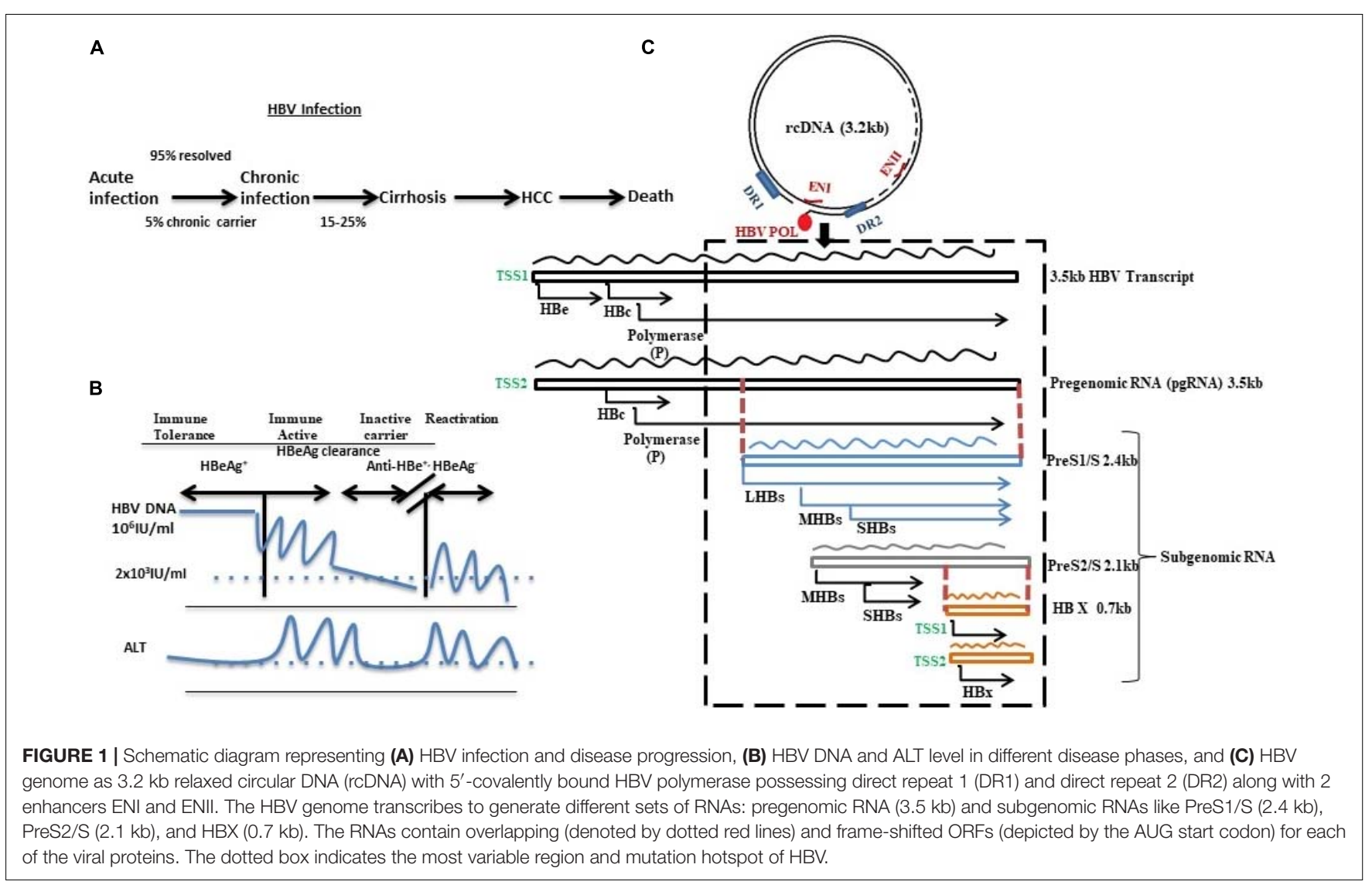

(Liu Y. et al., 2019; Lin et al., 2020, Gao et al., 2017). Studies also suggest that pgRNA remains in the serum of the patients who are under nucleot(s)ide analog (NA) therapy for a long time (Butler et al., 2018; Cloherty et al., 2019; Pan et al., 2021) when viral DNA copy number reduces to an undetectable level. The NA therapy does not completely inhibit the reverse transcription from pgRNA and thus there is a risk of viral reactivation after cessation of NA treatment. Although published data suggest that HBV RNA plays an important role in HBV-mediated disease progression directly or indirectly, the role of pgRNA in the secreted virion-like particle and the infection potential of this particle need to be studied further. Thus, pgRNAs may be considered as a new serum biomarker for judging HBV infection, treatment response, and disease prognosis (Li et al., 2013; Wang et al., 2013; Deng et al., 2016; Takata et al., 2016; Halgand et al., 2018; Wang et al., 2018b; Cloherty et al., 2019).

\section{HBV RNAs in the Development of HCC}

Although the impact of HBV RNA in HCC development has been rarely reported, Ding et al. (2021) showed evidences that the high serum pgRNA level is associated with poor HCC survival and higher recurrence level after hepatectomy. It enhances overall cell proliferation, stemness, and tumorigenicity by overexpressing IGF2BP3 oncoprotein (Ding et al., 2021). Hence, pgRNA may be considered as a detector of HCC and also as a therapeutic target. Contrastingly, using 99 tumor tissues, Halgand et al. (2018) have depicted that both pgRNA and cccDNA in tumors are correlated to the absence of microvascular invasion and survival of the patients (Halgand et al., 2018). The gene expression analysis revealed that pgRNA-positive HCC had low expression of cell cycle and DNA repair genes, while higher expression of NTCP receptors and HBV DNA indicates well-differentiated HCC (Halgand et al., 2018; Ding et al., 2021). Thus, quantification of pgRNA from the non-integrated HBV could be a marker for viral replication and disease prognosis. Altinel et al. (2016) have also showed that nontumor (NT) liver tissue has twofold more $\mathrm{HBV}$ expression with a predominance of preS2/S mRNA while the expression of preS1, core, and $\mathrm{X}$ were lower in the tumor (T) as observed by the transcriptional mapping using CAGE (cap analysis of gene expression) (Altinel et al., 2016).

In contrast to the heterogeneous pool of $\mathrm{HBV}$ transcripts detected in the liver, the corresponding blood samples showed predominance in pgRNA. In addition, shorter $\mathrm{HBx}$ transcripts encoding N-terminally truncated $\mathrm{HBxAg}$ were found in abundance in both T and NT compared with the canonical HBx, which is consistent with the reports suggesting that truncated HBxAg plays an important role in hepatocarcinogenesis (Altinel et al., 2016).

Apart from these canonical transcripts, about 22 spliced variants (spHBV) have also been detected in $\mathrm{HBV}$-infected patients; 18 variants of pgRNA and 4 of preS2/S (Chen et al., 1989, 2015; Su et al., 1989; Terré et al., 1991; Wu et al., 1991; Rosmorduc et al., 1995; Günther et al., 1997; Sommer et al., 2000; Hass et al., 2005; Abraham et al., 2008; Candotti et al., 2012; El Chaar et al., 2012; Betz-Stablein et al., 2016; Lam et al., 2017; Ito et al., 2019). Among these, hepatitis B spliced protein (HBSP), which 
originates from 2.2-kb splice variants, are abundantly found in both T and NT tissues (Lin et al., 2002; Soussan et al., 2003). Ectopic expression of HBSP in hepatoma cells restricts $\mathrm{TNF} \alpha-$ mediated hepatic inflammation and subsequently reduces the immune infiltration in liver. In addition, it can also promote antiapoptotic effect by inducing PI3K/AKT activity and preventing FAS-induced apoptosis (Pol et al., 2015; Wu et al., 2018). Its interaction with cathepsin B promotes cellular migration and invasion via activating MMP9 and urokinase-type plasminogen activator (uPA), enhancing tumor-induced vascularization of endothelial cells and activation of MAPK/AKT Signaling (Chen et al., 2012). Bayliss et al. (2013) investigated the level of spHBV in a cohort of $58 \mathrm{HBV}$ patients from pre-HCC state to post-HCC state and found that $\sim 38 \%$ patients had high spHBV level $1-$ 3 years before HCC diagnosis while the percentage rose to $50 \%$ during the diagnosis of HCC (Bayliss et al., 2013). Thus, the level of spHBV could be a good HCC prognostic marker.

\section{Impact of cccDNA on Persistence of Liver Diseases}

Hepatic nuclear cccDNA serves as a repertoire of HBV DNA in patients. Several evidences have suggested that the virological relapse of hepatitis after completion of NA therapy often occurs because of the presence of nuclear cccDNA, which is not affected by NA as these are inhibitors of reverse transcriptase. Thus, the synthesis of pgRNA and viral proteins is continued for a certain period after therapy. Only a few copies of cccDNA are sufficient to reactivate the $\mathrm{HBV}$ replication after therapy withdrawal. Various advanced techniques such as direct cccDNA degradation strategies including Crisper-Cas9 (Ramanan et al., 2015; Yang et al., 2020), transcription activator-like effector nucleases (TALENs) (Chen et al., 2014; Bloom et al., 2019), and zinc finger nucleases (ZFNs) (Cradick et al., 2010) have been investigated. More conclusive studies may be needed to test the efficacy and safety of the molecules that could be used in the clinical trials.

The cccDNA is stable in the quiescent hepatocyte and it acts as a viral mini-chromosome organized by host nuclear histones and non-histone proteins, which protect the DNA from intracellular DNase. The level of cccDNA in the nucleus is independent of HBV-DNA level; treatment of HBV neutralizing antibody could not block cccDNA as observed in cell culture model (Dandri and Peterson, 2020). It is epigenetically regulated because it consists of six $\mathrm{CpG}$ islands of which three are conventional and involve in silencing by methylation. DNMTs reduce pgRNA transcription and hence restrict reverse transcription of viral genome (Zhang et al., 2013, 2014; Jain et al., 2015; Zhu et al., 2019). Viral trans-activating protein $\mathrm{HBx}$ is an important factor in de-silencing cccDNA, which is involved in its hyperacetylation either by blocking the inhibitory effect of methyltransferases like PRMT1 and SETDB1 or Tudor-domain protein Spindlin-1 (Benhenda et al., 2013; Ducroux et al., 2014; Riviere et al., 2015). Depuration by APOBEC3 deaminases in the presence of IFN- $\alpha$ and TNF- $\alpha$ can also reduce cccDNA (Lucifora et al., 2014), but the concentration of IFN- $\alpha$ used for HBV elimination in patients does not affect cccDNA (Niederau et al., 1996; Lau et al., 2005).
On the other hand, the cccDNA is the origin of HBV DNA; the quantification of cccDNA requires liver tissue which is not feasible in all patients. Several ongoing studies have found a correlation between serum pgRNA and transcriptional activity of cccDNA in HBV patients. Gao et al. (2017) have showed that in pretreated condition, HBV-DNA level better reflects intrahepatic cccDNA level in comparison with HBV-RNA and HBsAg, while after 96 weeks of NA therapy, intracellular cccDNA level correlates mainly with HBsAg level (Gao et al., 2017; Huang et al., 2018; Wang et al., 2018b; Liu Y. et al., 2019). Giersch et al. (2017) have also reported that serum pgRNA level reflects the intracellular pgRNA in humanized uPA/SCID/beige mice model of HBV after NA therapy while in NA untreated mice, serum pgRNA level was comparable with both the intracellular pgRNA and cccDNA level (Giersch et al., 2017). Thus, it is important to quantify both serum HBV pgRNA and serum HBV DNA than serum HBV DNA alone before withdrawal of NA therapy.

Several evidences have showed that $\mathrm{HBx}$ also represses several miRNAs like miR-138, miR-224, and miR-596, which inhibits viral replication by targeting the HBV pregenomic RNA (pgRNA). HBx also interacts with long non-coding RNA, DLEU2, to relieve the silencing effect of EZH2/PRC2 on the cccDNA transcription. Apart from host liver-specific transcription factors, $\mathrm{HBx}$ is also an indispensable factor for an efficient cccDNA transcription (Li et al., 2013; Wang et al., 2013; Deng et al., 2016; Takata et al., 2016; Guerrieri et al., 2017; Salerno et al., 2020).

\section{Viral Genetic Variability on Persistence of the HBV Infection}

Depending on the $8 \%$ sequence variations in the entire genome, $\mathrm{HBV}$ is genotyped into 10 including $\mathrm{A}$ to $\mathrm{J}$, while each genotype is again sub-genotyped on considering $4 \%$ sequence alterations (Kramvis, 2014). To date, HBV genotype A (A1A7), genotype $\mathrm{B}$ (B1-B9), genotype $\mathrm{C}(\mathrm{C} 1-\mathrm{C} 6)$, genotype $\mathrm{D}$ (D1-D10), and genotype F (F1-F4) are most studied as these genotypes/subgenotypes showed distinct distribution pattern worldwide along with the disease manifestations. Apart from this, recombinant strains $(\mathrm{A} / \mathrm{D}, \mathrm{A} / \mathrm{E}, \mathrm{C} / \mathrm{D}$, and $\mathrm{G} / \mathrm{C})$ are also observed in different geographical regions (Cui et al., 2002; Simmonds and Midgley, 2005; McMahon, 2009; Araujo, 2015). Recently, C/D recombinant strain of $\mathrm{HBV}$, subgenotype $\mathrm{D} 9$, has been found among HBeAg-negative $\mathrm{CHB}$ patients from Eastern India (Ghosh et al., 2013). Among these genotypes and subgenotypes, western data showed genotype A-infected patients had high rate of HBV surface antigen clearance along with rapid reduction of viral DNA and sustained improvement of biochemical parameters (Sanchez-Tapias et al., 2002) while a Chinese study depicted that both HBsAg clearance is better for genotypes A and B than genotypes C and D (Lin and Kao, 2015). Studies also suggest that patients with genotypes $\mathrm{C}$ and $\mathrm{D}$ were more vulnerable to advanced diseases such as liver cirrhosis and HCC (El-Serag, 2012) and showed delayed HBeAg clearance. One study with Alaskan natives reported that genotype C2 and F develop HCC more than genotype A2, B6, and D (McMahon, 2009). In India, subgenotypes D1 and D3 have been found to be associated with advanced diseases though D2 showed highest replication 
efficiency (Datta et al., 2018; Khatun et al., 2018). Although genotype $\mathrm{D}$ has been reported as an independent risk factor for fulminant hepatitis (Thukar et al., 2002; Wai et al., 2005), genotype $G$ is rarely seen alone. It is co-infected with other genotypes particularly genotype $\mathrm{A}$. Genotypes $\mathrm{F}$ and $\mathrm{H}$ are observed in an indigenous population of South America (Devesa et al., 2004). Patients with genotype $\mathrm{C}$ with $\mathrm{HBeAg}$ negative are at high risk of progression of $\mathrm{CHB}$ to cirrhosis and $\mathrm{HCC}$ (Chan et al., 2004).

\section{Mutations Accumulated in HBV Genome and Its Impact on Disease Progression}

Hepatitis B virus, although being a DNA virus, yet exhibits a much higher mutation rate than other DNA viruses (Echevarría and Avellón, 2006). The evolutionary rate of $\mathrm{HBV}$ is $10^{-5}$ to $10^{-4}$ substitution/site/year, which is almost equivalent to the RNA viruses (Osiowy et al., 2006; Zhou and Holmes, 2007; Wang et al., 2010). Because the ORFs are overlapping in most of the synonymous substitutions in one frame, it may or may not result in synonymous change in the other. For example, deletions in PreS1 and PreS2 or start codon mutations in PreS2 or premature stop codon substitution in $\mathrm{S}$ are not only associated with longlasting chronic HBV infection but are also highly associated with increasing risk for HCC development. High viral load and high replication efficiency result in overload of viral proteins including misfolded and unfolded ones in ER/Golgi apparatus increasing unfolded protein response (UPR) (Lazar et al., 2014; Kim et al., 2017; Choi et al., 2019). Normally, excessive accumulation of envelope proteins in the ER/Golgi apparatus results in budding of dimerized or multimerized envelope proteins without enclosed viral genome leading to secretion of non-infectious spherical or filamentous subviral particles (SVPs) (Patient et al., 2009; Selzer and Zlotnick, 2015). Outnumbered SVPs compared with the infectious virions in the circulation often lead to immune tolerance, which sums up to viral persistence. Moreover, the ratio of $\mathrm{L}$ and $\mathrm{S}$ envelope proteins is an important deciding factor for a proper assembly and maintenance of cccDNA pool. The differential regulation of the LHBs and other $\mathrm{HB}$ proteins is due to the presence of two independent promoters. This leads to a temporal and differential effect of the envelope proteins on the viral life cycle as well as the cellular processes. The promoter for pre-S1 or L envelope proteins is different from pre-S2 or pre$\mathrm{S}$ promoter. Moreover, the production of $\mathrm{L}$ proteins is much less than the other surface proteins. Thus, the overproduction of L proteins either due to naturally occurring deletion and/or point mutations in the $S$ promoter CCAAT element or due to differential expression of the host trans-acting factors may result in altered viral assembly and secretion. This causes ER stress owing to overload of viral surface proteins. Both the LHBs and the consequent ER stress trigger the synthesis of the MHBs and HBs, which in turn result in increased secretion of both non-infectious and infectious virion particles (Ou and Rutter, 1987; Bock et al., 1999; Summers et al., 1991; Xu et al., 1997; Pollicino et al., 2014). The histological hallmark of chronic HBV infection is ground glass hepatocyte due to excessive accumulation of HBsAg. These hepatocytes possess a huge amount of LHBs containing filamentous particles in the ER/Golgi bodies (Wang et al., 2003; Su et al., 2008).

Mutations in the "a" determinant of HBsAg are very common in chronic $\mathrm{HBV}$ patients leaving anti-HBc antibody as the only detectable marker for infection. These mutations lead to alterations in the conformation of the surface antigen offering false-negative result in the commercially available surface antigen detection kit (Weber, 2005; Pawlotsky, 2005). The first vaccine escape mutant identified was glycine to arginine change at 145 residue of HBsAg (sG145R). Selective pressure to persistence of this mutant is observed in case of HBIG administration during liver transplantation (Carman et al., 1990; Ghany et al., 1998). In such event, despite having active $\mathrm{HBV}$ infection with high viral load, the detection of HBsAg is limited. Further study with DNA immunization in BALB/C mice revealed that glycosylation of surface could reduce antigenicity (Bolhassani and Yazdi, 2009). Mutations located at T123N, K122I, A159G, and K160N cause over-glycosylation in HBsAg, which also reduces antigenicity and induces viral persistence (Torresi et al., 2002; Wu et al., 2010).

\section{Integration of HBV DNA and HBV Persistence}

Integration of viral DNA into the host chromosome is a very common event observed in CHB and HCC (Mason et al., 2005, 2009 , 2010). The parsimonious nature of the viral genome suggests chromosomal integration of the viral genome may not decrease the replication fitness of the virus. Both in vitro HBV infection in HepaRG and HepG2 cell line and histological evidences of chronic $\mathrm{HBV}$ revealed that $\mathrm{HBV}$ integration could be a very early event, and it is considered as one of the reasons for the development of liver cirrhosis and HCC. Woodchuck HBV infection model with respective virus also shows similar event days after infection (Bud and Gerin, 2001; Mason et al., 2005).

The recent next-generation sequencing data suggest that the integration of the viral genome in the non-tumor tissue is dispersed throughout the genome with no hotspot while tumor tissue showed enrichment of particular genomic sites such as MLL4, TERT, and CTNNB1 (Zhao et al., 2016; An et al., 2018). Now the question is about the fate of the integrated DNA. This integrated form cannot produce pgRNA, and it is replication incompetent. The expression of all viral transcripts is altered due to random integration of HBV DNA in the host genome, while only HBsAg transcript expresses constitutively from its native promoter. Other transcripts such as $\mathrm{HBeAg} / \mathrm{HBcAg}$ may be produced using cellular promoter located upstream of the integration site and the transcript of the oncogenic protein $\mathrm{HBx}$ is either truncated or fused with other transcripts (Valenzuela et al., 1979; Edman et al., 1980; Twist et al., 1981; Lee et al., 1999; Podlaha et al., 2019; Zhao et al., 2020).

The frequency of integration of viral DNA is observed more in the tumor tissue (T) than in the non-tumor tissue (NT) (Arbuthnot and Kew, 2001; Hai et al., 2014; Budzinska et al., 2018). Again, intact HBV DNA integration is more common in the chronic hepatitis $\mathrm{B}$ and cirrhotic stages 


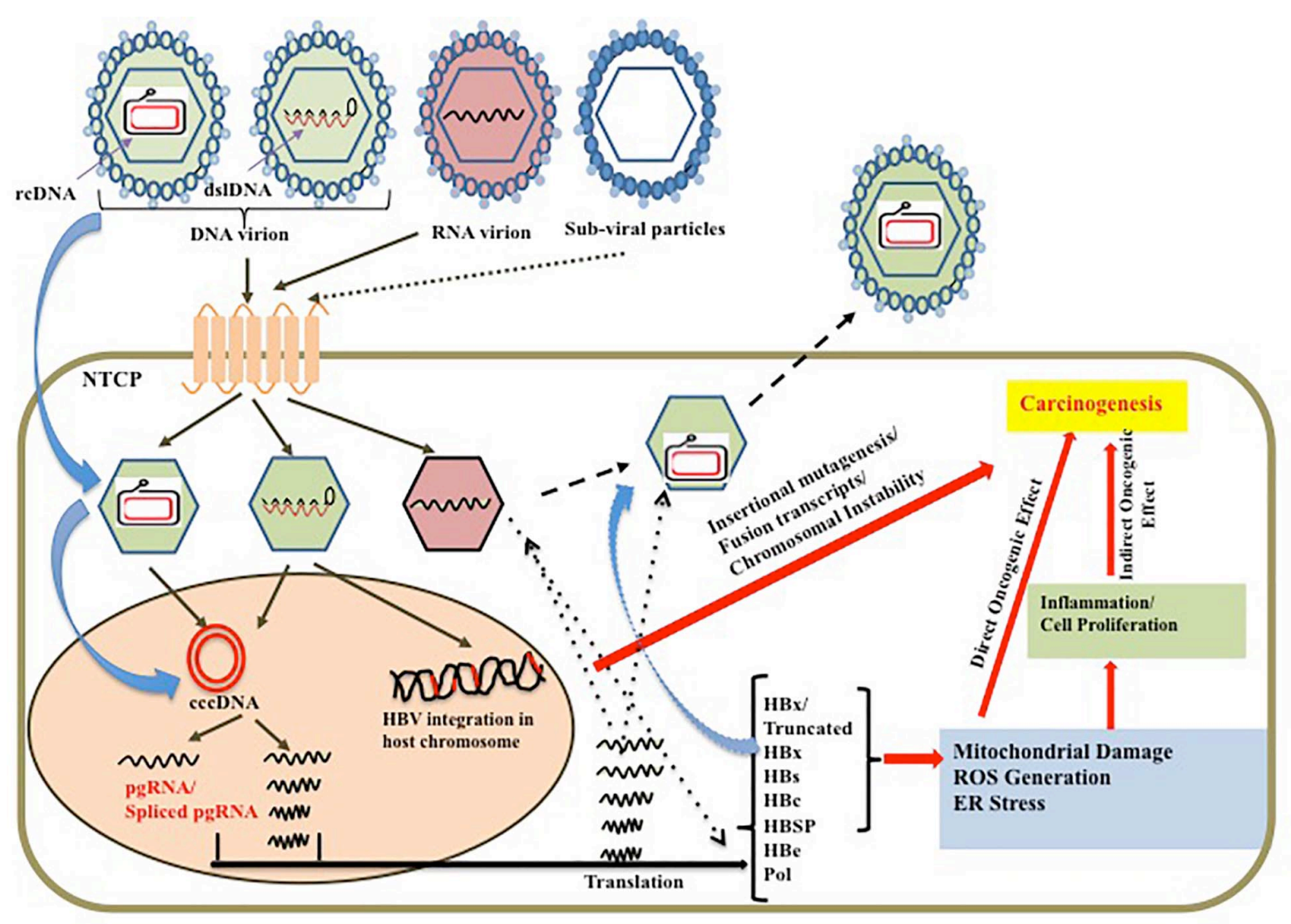

FIGURE 2 | Schematic representation of the causal factors for HBV persistence leading to predisposed oncogenic effect on liver along with the direct oncogenic effect of the viral genome and proteins on hepatocarcinogenesis.

than in HCC (Aoki and Robinson, 1989). This could lead to accumulation of deleterious fusion products associated with hepatocarcinogenesis.

The HBV antigens could be expressed from the integrated viral sequences. If only $1 \%$ of the hepatocytes express viral antigens and are enriched, then the liver could be a persistent reservoir of $\mathrm{HBV}$ proteins. Proteins expressed from the integrated form may support replication of an incompetent strain in trans. In addition, accumulation of mutant HBsAg often causes ER stress and UPR, induces stem-like properties, enhances cellular growth, reduces apoptosis, and thus triggers liver disease progression toward HCC.

\section{Oncogenic Properties of Occult HBV Infection and Persistence of HBV}

The occult HBV infection (OBI) in patients with anti-HBsAg is another important reason for the persistence of $\mathrm{HBV}$ infection, which causes viral reactivation during immune suppression. Our group has reported recently that among $238 \mathrm{HCV}$-infected patients, 38 patients (18\%) were with OBI while $66.8 \%$ were without $\mathrm{OBI}$ but having anti- $\mathrm{HBs}^{+} /$anti- $\mathrm{HBc}^{+}(13 \%)$, anti$\mathrm{HBs}^{+} / \mathrm{anti}_{-\mathrm{HBc}^{-}}(10 \%)$, and anti-HBs${ }^{-} / \mathrm{anti}_{-} \mathrm{HBc}^{+}$(25\%). Here, $90 \%$ of patients have common HBsAg-associated mutations in the "a determinant region" T125M and P127T (Mondal et al., 2017). These two mutations were also found among OBI patients in Greek and Egyptian blood donors (Zheng et al., 2004; Mina et al., 2010; Elbahrawy et al., 2015). Using in vitro experiment and in silico analysis, we have showed that these two mutations do not alter the HBsAg production but antigenicity drops. A similar report was documented by Velay et al. (2016). Hence, these two mutant variants could be the reason of persistent infection by evading the host immunity even in vaccinated hosts. Apart from this, P33S mutation in B-cell epitope located in HBx gene; I42L in PreS2; spH153L and rtS135Y in polymerase; 1050G, A1053G, C1059T, and C1350A in enhancer I and PreS2/S promoter region; and $\mathrm{C} 1637 \mathrm{~A}$ and $\mathrm{T} 1676 \mathrm{~A}$ in enhancer II region were found in high number in OBI patients (Mondal et al., 2017). In addition, three mutations in polymerase gene rtV278I, rhL30S, and rhL55I, which generate four alterations in overlapping $\mathrm{HBx}$ gene promoter region (G961A, C1249T, T1250C, and C1324A), are also responsible for the low replication efficiency of the virus. In China, PreS1/S mutations T68I and sQ129R/L were found to be associated with anti-HBsAg ${ }^{+} \mathrm{OBI}$, while sS167 and sA166 were found in the major hydrophilic region (Wang et al., 2020). These are all immune escape mutants. Thus, OBI could be the high risk for the development of endstage diseases. 


\section{Pro-Oncogenic Properties of HBV Proteins on Disease Persistence}

Among the viral proteins of $\mathrm{HBV}, \mathrm{HBx}$ is a multifunctional viral protein having pleiotropic role including development and progression of HCC. Compartmentalized location of $\mathrm{HBx}$ within the cell is critical for its various functions in the tumor microenvironment. Presence of this protein in the cytoplasm triggers multiple signal-transduction pathways related to development, invasion, migration, and recurrence of HCC. These include Wnt/ $\beta$-catenin, nuclear factor $\kappa$-light-chain enhancer of activated B cells (NF- $\kappa$ B), Janus kinase/signal transducer and activator of transcription (STAT), and Ras/Raf/mitogenactivated protein kinase (MAPK) pathways. Also, nuclear $\mathrm{HBx}$ functions as transactivator of gene regulation for several proto-oncogenes (c-Myc, N-Myc and c-Jun) and activating protein-1 (AP-1), NF-kB, and ATF/CREB (Zhang et al., 2006; Ali et al., 2014; Geng et al., 2015). A recent study shows that this viral protein interacts with HIF- $1 \alpha$ and HIF-1 $\alpha$ target genes like lysyl oxidase (LOX) family in HCC. Thus, it regulates cell-cycle checkpoints, proliferation, apoptosis, and DNA repair. HBx disrupts mitochondrial stability by downregulating various enzymes and promoting reactive oxygen species (ROS) production and also lipid peroxidation. This causes intracellular damage, metastasis, and resistance to cell death. The impact of this protein on HBV replication triggers endoplasmic reticulum stress. HBx also induces autophagy by PI3/AKT/mTOR pathway (Lee et al., 2004; Park et al., 2007; Fu et al., 2016).

Most interestingly, it plays an important role in promoting apoptotic death in virus-specific $\mathrm{CD} 8^{+} \mathrm{T}$ lymphocytes and reduces the production of IFN- $\gamma$, which leads to attenuation of immune response and persistence of the disease. Selective regulation of multiple proinflammatory cytokines including IL8, IL-18, IL-23, and TNF- $\alpha$ triggers HCC pathogenesis (Wu et al., 2010). Thus, the activity of $\mathrm{HBx}$ in the tumor microenvironment is a new therapeutic target for HCC.

Mutated preS2 proteins also confer their oncogenic properties by triggering degradation of $\mathrm{p} 27$, hyper-phosphorylating $\mathrm{pRb}$, and promoting cell cycle progression. It is also known to promote overexpression of cyclin A, COX2, and TERT. In addition, 3 ' deleted $\mathrm{preS} / \mathrm{S}$ sequence infers its oncogenic potential by inducing transcription factors like AP1 and NF- $\kappa \beta$ and thereby increasing hepatocyte proliferation (Yen et al., 2016). Overall, the persistent HBV life cycle directly confers to the malignant transformation of the hepatocytes.

\section{Failure of Immune Control and HBV Persistence}

In the immune active phase, persistent HBV infection leads to the progression of the underlying chronic liver diseases characterized by persistent inflammation and immune dysfunction (Tan et al., 2015). The pro-inflammatory cytokines like IL-2, IL-7, IL-6, and IFN- $\gamma$ are overproduced in the milieu leading to necro-inflammation, cellular stress, epigenetic modulations, and DNA damage (Abb et al., 1985; Bozkaya et al., 2000; Lan et al., 2015; Zhong et al., 2016).
Such persistent hepatocyte damage and chronic antigen stimulation activate the non-parenchymal cells, alter intracellular cross-talks and T-cell exhaustion leading to tumorigenesis, and develop a tumor immune microenvironment (TIME), which is immunosuppressive in nature. The prime player in maintaining such immunosuppressive microenvironment is the increased abundance of Tregs via $\mathrm{HBx}$-stimulated production of transforming growth factor- $\beta 1$ (TGF- $\beta 1$ ) and increased frequency of monocytic-myeloid derived suppressor cells (mMDSCs) (Li et al., 2016; Pal et al., 2019). mMDSCs and Treg cells may lead to overexpression of IL10, which results in persistent immunosuppressive nature of TIME in HBV-infected HCC (Chen et al., 2011; Kondo and Shimosegawa, 2015; Tu et al., 2016). Blocking of PD-1/PD-L1 axis in chronic HBV patients can partially reverse the immune suppression by reducing the T-cell exhaustion (Féray and López-Labrador, 2019; Li et al., 2020). Moreover, HBV persistence leads to accumulation of surface proteins in the ER and triggers ER stress, which may release exosomal miRNAs like miR-23a-3p that in turn can upregulate PD-L1 expression by tumorassociated macrophages (TAMs) (Liu J. et al., 2019). In addition, exosomes from HBV-infected cells express interferon-induced transmembrane protein 2 (IFITM2), which inhibits the synthesis of IFN- $\alpha$ in clonally expanded plasmacytoid dendritic cells (Shi et al., 2019). Impairment of $\mathrm{CD}^{+}$follicular helper T cells may also potentiate development of HCC in HBV-positive patients (Chen and Tian, 2019). However, there is an overall immunological heterogeneity in HCC due to difference in infiltrated leukocyte composition in TIME. Leukocyte-enriched HCC is termed as inflamed HCC while poor leukocyte enrichment is known as non-inflamed HCC (Trujillo et al., 2018). In HBV-associated HCC, increased M2 polarization of macrophages mainly mediated by $\mathrm{HBsAg}$ stimulation results in enhanced production of anti-inflammatory IL-10 and TGF- $\beta$, probably via inhibition of JNK, ERK, and NF-KB signaling (Yang et al., 2014). Thus, failure of immune control is one of the major reasons of HBV persistence and disease progression toward HCC.

\section{CONCLUSION}

Hepatitis B virus is a unique DNA virus which has a complex strategy to persist inside the cell. It exists as a minichromosomelike structure called cccDNA in the host nucleus, which maintains the viral reservoir and serves as the source of the viral RNA and viral proteins. The complex viral replication strategy leads to generation of myriads of RNA intermediates including the pre-genomic RNA (pgRNA) and other subgenomic RNAs. The specialty of the viral genome is in its overlapping and frame-shifted ORFs, which results in differential regulation and expression of the viral proteins. In addition, such overlapping sequences result in the synergistic effect of the mutations in more than one frame. Such genomic variability along with the overload of the viral proteins in ER/Golgi apparatus increases the UPR thereby leading to stress. Such prolonged induction of stress associated with direct or indirect effect of the virus on the cellular 
apoptosis and proliferation results in the disease progression toward carcinoma. Moreover, the viral oncoprotein HBx is one of the prime factors that interacts with several host proteins and modulates the signaling pathways to aid in the process of hepatocarcinogenesis. In addition, the integration process not only increases the genome instability but also generates several fused and/or truncated or altered viral and host proteins, which aids in the hepatocarcinogenesis process. Lastly, the prolonged exposure to HBsAg in the circulation results in the imbalance in the immune response leading to development of an immune-tolerant microenvironment, which facilitates the tumor progression. The overview of the complex crosstalk of the viral persistence with hepatocarcinogenesis is presented in Figure 2.

\section{REFERENCES}

Abb, J., Zachoval, R., Eisenburg, J., Pape, G. R., Zachoval, V., and Deinhardt, F. (1985). Production of interferon alpha and interferon gamma by peripheral blood leukocytes from patients with chronic hepatitis B virus infection. J. Med. Virol. 16, 171-176.

Abraham, T. M., Lewellyn, E. B., Haines, K. M., and Loeb, D. D. (2008). Characterization of the contribution of spliced RNAs of hepatitis B virus to DNA synthesis in transfected cultures of Huh7 and HepG2 cells. Virology 379, 30-37. doi: 10.1016/j.virol.2008.06.021

Ali, A., Abdel-Hafiz, H., Suhail, M., Al-Mars, A., Zakaria, M. K., Fatima, K., et al. (2014). Hepatitis B virus, HBx mutants and their role in hepatocellular carcinoma. World J. Gastroenterol. 20, 10238-10248. doi: 10.3748/wjg.v20.i30. 10238

Altinel, K., Hashimoto, K., Wei, Y., Neuveut, C., Gupta, I., Suzuki, A. M., et al. (2016). Single-nucleotide resolution mapping of hepatitis B virus promoters in infected human livers and hepatocellular carcinoma. J. Virol. 90, 10811-10822. doi: 10.1128/jvi.01625-16

An, P., Xu, J., Yu, Y., and Winkler, C. A. (2018). Host and viral genetic variation in HBV-related hepatocellular carcinoma. Front. Genet. 9:261. doi: 10.3389/fgene. 2018.00261

Aoki, N., and Robinson, W. S. (1989). State of hepatitis B viral genomes in cirrhotic and hepatocellular carcinoma nodules. Mol. Biol. Med. 6, 395-408.

Araujo, N. M. (2015). Hepatitis B virus intergenotypic recombinants worldwide: an overview. Infect. Genet. Evol. 36, 500-510. doi: 10.1016/j.meegid.2015.08.024

Arbuthnot, P., and Kew, M. (2001). Hepatitis B virus and hepatocellular carcinoma. Int. J. Exp. Pathol. 82, 77-100.

Bayliss, J., Lim, L., Thompson, A. J. V., Desmond, P., Angus, P., Locarnini, S., et al. (2013). Hepatitis B virus splicing is enhanced prior to development of hepatocellular carcinoma. J. Hepatol. 59, 1022-1028. doi: 10.1016/j.jhep.2013. 06.018

Benhenda, S., Ducroux, A., Rivière, L., Sobhian, B., Ward, M. D., Dion, S., et al. (2013). Methyltransferase PRMT1 is a binding partner of HBx and a negative regulator of hepatitis B virus transcription. J. Virol. 87, 4360-4371. doi: 10.1128/ jvi.02574- 12

Betz-Stablein, B. D., Töpfer, A., Littlejohn, M., Yuen, L., Colledge, D., Sozzi, V., et al. (2016). Single-molecule sequencing reveals complex genome variation of hepatitis B virus during 15 years of chronic infection following liver transplantation. J. Virol. 90, 7171-7183. doi: 10.1128/jvi.00243-16

Bloom, K., Kaldine, H., Cathomen, T., Mussolino, C., Ely, A., Arbuthnot, P., et al. (2019). Inhibition of replication of hepatitis B virus using transcriptional repressors that target the viral DNA. BMC Infect. Dis. 19:802. doi: 10.1186/ s12879-019-4436-y

Bock, C. T., Tillmann, H. L., Manns, M. P., and Trautwein, C. (1999). The pre-S region determines the intracellular localization and appearance of hepatitis $\mathrm{B}$ virus. Hepatology 30, 517-525. doi: 10.1002/hep.510300206

Bolhassani, A., and Yazdi, S. R. (2009). DNA immunization as an efficient strategy for vaccination. Avicenna J. Med. Biotechnol. 1, 71-88.

Bozkaya, H., Bozdayi, M., Türkyilmaz, R., Sarioglu, M., Cetinkaya, H., Cinar, K., et al. (2000). Circulating IL-2, IL-10 and TNF-alpha in chronic hepatitis

\section{AUTHOR CONTRIBUTIONS}

SG and AC had prepared the manuscript. SB had thoroughly read and finalized the manuscript. All authors contributed to the article and approved the submitted version.

\section{ACKNOWLEDGMENTS}

SG received Senior Research Fellowship from University Grant Commission (UGC), New Delhi, Government of India.

B: their relations to $\mathrm{HBeAg}$ status and the activity of liver disease. Hepatogastroenterology 47, 1675-1679.

Bud, C. T., and Gerin, J. L. (2001). The woodchuck model of hepatitis B virus infection. ILAR J. 42, 89-102.

Budzinska, M. A., Shackel, N. A., Urban, S., and Tu, T. (2018). Cellular genomic sites of hepatitis B virus DNA integration. Genes 9:365. doi: 10.3390/ genes 9070365

Butler, E. K., Gersch, J., McNamara, A., Luk, K. C., Holzmayer, V., de Medina, M., et al. (2018). Hepatitis B virus serum DNA and RNA levels in nucleos(t)ide analog-treated or untreated patients during chronic and acute infection. Hepatology 68, 2106-2117. doi: 10.1002/hep. 30082

Candotti, D., Lin, C. K., Belkhiri, D., Sakuldamrongpanich, T., Biswas, S., Lin, S., et al. (2012). Occult hepatitis B infection in blood donors from South East Asia: molecular characterisation and potential mechanisms of occurrence. Gut 61, 1744-1753. doi: 10.1136/gutjnl-2011-301281

Carman, W. F., Zanetti, A. R., Karayiannis, P., Waters, J., Manzillo, G., Tanzi, E., et al. (1990). Vaccine-induced escape mutant of hepatitis B virus. Lancet 336, 325-329. doi: 10.1016/0140-6736(90)91874-a

Chan, H. L., Hui, A. Y., Wong, M. L., Tse, A. M., Hung, L. C., Wong, V. W., et al. (2004). Genotype C hepatitis B virus infection is associated with an increased risk of hepatocellular carcinoma. Gut 53, 1494-1498. doi: 10.1136/gut.2003. 033324

Chen, J., Wu, M., Wang, F., Zhang, W., and Yuan, Z. (2015). Hepatitis B virus spliced variants are associated with an impaired response to interferon therapy. Sci. Rep. 5:16459.

Chen, J., Zhang, W., Lin, J., Wang, F., Wu, M., Chen, C., et al. (2014). An efficient antiviral strategy for targeting hepatitis B virus genome using transcription activator-like effector nucleases. Mol. Ther. 22, 303-311. doi: 10.1038/mt.2013. 212

Chen, P. J., Chen, C. R., Sung, J. L., and Chen, D. S. (1989). Identification of a doubly spliced viral transcript joining the separated domains for putative protease and reverse transcriptase of hepatitis B virus. J. Virol. 63, 4165-4171. doi: 10.1128/jvi.63.10.4165-4171.1989

Chen, S., Akbar, S. M., Abe, M., Hiasa, Y., and Onji, M. (2011). Immunosuppressive functions of hepatic myeloid-derived suppressor cells of normal mice and in a murine model of chronic hepatitis B virus. Clin. Exp. Immunol. 166, 134-142.

Chen, W. N., Chen, J. Y., Jiao, B. Y., Lin, W. S., Wu, Y. L., Liu, L. L., et al. (2012). Interaction of the hepatitis B spliced protein with cathepsin B promotes hepatoma cell migration and invasion. J. Virol. 86, 13533-13541. doi: 10.1128/ jvi.02095-12

Chen, Y., and Tian, Z. (2019). HBV-induced immune imbalance in the development of HCC. Front. Immunol. 10:2048.

Choi, Y. M., Lee, S. Y., and Kim, B. J. (2019). Naturally occurring hepatitis B virus mutations leading to endoplasmic reticulum stress and their contribution to the progression of hepatocellular carcinoma. Int. J. Mol. Sci. 20:597. doi: 10.3390/ijms20030597

Cloherty, G., Butler, E., and Kuhns, M. (2019). Serum hepatitis B Virus RNA as a potential diagnostic biomarker during chronic hepatitis B virus infection. Clin. Liver Dis. 13, 90-92. doi: 10.1002/cld.774 
Cradick, T. J., Keck, K., Bradshaw, S., Jamieson, A. C., and McCaffrey, A. P. (2010). Zinc-finger nucleases as a novel therapeutic strategy for targeting hepatitis B virus DNAs. Mol. Ther. 18, 947-954. doi: 10.1038/mt.2010.20

Cui, C., Shi, J., Hui, L., Xi, H., Zhuoma, Quni. et al. (2002). The dominant hepatitis $\mathrm{B}$ virus genotype identified in Tibet is a C/D hybrid. J. Gen. Virol. 83, 2773-2777. doi: 10.1099/0022-1317-83-11-2773

Cui, X., McAllister, R., Boregowda, R., Sohn, J. A., Cortes Ledesma, F., Caldecott, K. W., et al. (2015). Does tyrosyl DNA phosphodiesterase-2 play a role in hepatitis B virus genome repair? PLoS One 10:e0128401. doi: 10.1371/journal. pone.0128401

Dandri, M., and Peterson, J. (2020). cccDNA maintenance in chronic hepatits B-Targeting the matrix of viral replication. Infect. Drug Resist. 2020, 3873-3886.

Datta, S., Dasgupta, D., Ghosh, A., Ghosh, S., Manna, A., Datta, S., et al. (2018). Oncogenic potential of hepatitis B virus subgenotype D1 surpasses D3: significance in the development of hepatocellular carcinoma. Carcinogenesis 39, 283-292. doi: 10.1093/carcin/bgx145

Deng, M., Hou, J., Hu, J., Wang, S., Chen, M., Chen, L., et al. (2016). Hepatitis $B$ virus mRNAs functionally sequester let-7a and enhance hepatocellular carcinoma. Cancer Lett. 383, 62-72. doi: 10.1016/j.canlet.2016.09.028

Devesa, M., Rodriguez, C., Leon, G., Liprandi, F., and Pujol, F. H. (2004). Clade analysis and surface antigen polymorphism of hepatitis B virus American genotypes. J. Med. Virol. 72, 377-384. doi: 10.1002/jmv.20015

Ding, W. B., Wang, M. C., Yu, J., Huang, G., Sun, D. P., Lei, L., et al. (2021). HBV-pgRNA increases the stemness and promotes the development of HBVrelated HCC through reciprocal regulation with IGF2BP3. Hepatology 7. doi: 10.1002/hep.31850

Ducroux, A., Benhenda, S., Riviere, L., Semmes, O. J., Benkirane, M., and Neuveut, C. (2014). The Tudor domain protein Spindlin 1 is involved in intrinsic antiviral defense against incoming hepatitis B Virus and herpes simplex virus type 1. PLoS pathogens 10:e1004343. doi: 10.1371/journal.ppat.1004343

Duriez, M., Mandouri, Y., Lekbaby, B., Wang, H., Schnuriger, A., Redelsperger, F., et al. (2017). Alternative splicing of hepatitis B virus: a novel virus/host interaction altering liver immunity. J. Hepatol. 67, 687-699. doi: 10.1016/j.jhep. 2017.05.025

Echevarría, J. M., and Avellón, A. (2006). Hepatitis B virus genetic diversity. J. Med. Virol. 78(Suppl.1), S36-S42.

Edman, J. C., Gray, P., Valenzuela, P., Rall, L. B., and Rutter, W. J. (1980). Integration of hepatitis $\mathrm{B}$ virus sequences and their expression in a human hepatoma cell. Nature 286, 535-538.

Elbahrawy, A., Alaboudy, A., El Moghazy, W., Elwassief, A., Alashker, A., and Abdallah, A. M. (2015). Occult hepatitis B virus infection in Egypt. World J. Hepatol. 7, 1671-1678. doi: 10.4254/wjh.v7.i12.1671

El Chaar, M., El Jisr, T., and Allain, J.-P. (2012). Hepatitis B virus DNA splicing in Lebanese blood donors and genotype A to E strains: implications for hepatitis B virus DNA quantification and infectivity. J. Clin. Microbiol. 50, 3159-3167. doi: $10.1128 / \mathrm{jcm} .01251-12$

El-Serag, H. B. (2012). Epidemiology of viral hepatitis and hepatocellular carcinoma. Gastroenterology 142, 1264.e-1273.e.

Féray, C., and López-Labrador, F. X. (2019). Is PD-1 blockade a potential therapy for HBV? JHEP Rep. 1, 142-144.

Fu, S., Zhou, R. R., Li, N., Huang, Y., and Fan, X. G. (2016). Hepatitis B virus $\mathrm{X}$ protein in liver tumor microenvironment. Tumour Biol. 37, 15371-15381. doi: 10.1007/s13277-016-5406-2

Gao, Y., Li, Y., Meng, Q., Zhang, Z., Zhao, P., Shang, Q., et al. (2017). Serum hepatitis B virus DNA, RNA, and HBsAg: which correlated better with intrahepatic covalently closed circular DNA before and after nucleos(t)ide analogue treatment? J. Clin. Microbiol. 55, 2972-2982. doi: 10.1128/jcm.0076017

Geng, M., Xin, X., Bi, L. Q., Zhou, L. T., and Liu, X. H. (2015). Molecular mechanism of hepatitis $\mathrm{B}$ virus $\mathrm{X}$ protein function in hepatocarcinogenesis. World J. Gastroenterol. 21, 10732-10738. doi: 10.3748/wjg.v21.i38.10732

Ghany, M. G., Ayola, B., Villamil, F. G., Gish, R. G., Rojter, S., Vierling, J. M., et al. (1998). Hepatitis B virus S mutants in liver transplant recipients who were reinfected despite hepatitis B immune globulin prophylaxis. Hepatology 27, 213-222. doi: 10.1002/hep.510270133

Ghosh, S., Banerjee, P., Deny, P., Mondal, R. K., Nandi, M., Roychoudhury, A., et al. (2013). New HBV subgenotype D9, a novel D/C recombinant, identified in patients with chronic HBeAg-negative infection in Eastern India. J. Viral. Hepat. 20, 209-218. doi: 10.1111/j.1365-2893.2012.01655.x

Giersch, K., Allweiss, L., Volz, T., Dandri, M., and Lutgehetmann, M. (2017). Serum HBV pgRNA as a clinical marker for cccDNA activity. J. Hepatol. 66, 460-462. doi: 10.1016/j.jhep.2016.09.028

Guerrieri, F., Belloni, L., D’Andrea, D., Pediconi, N., Le Pera, L., Testoni, B., et al. (2017). Genome-wide identification of direct HBx genomic targets. BMC Genomics 18:184. doi: 10.1186/s12864-017-3561-5

Günther, S., Sommer, G., Iwanska, A., and Will, H. (1997). Heterogeneity and common features of defective hepatitis B virus genomes derived from spliced pregenomic RNA. Virology 238, 363-371. doi: 10.1006/viro.1997.8863

Hai, H., Tamori, A., and Kawada, N. (2014). Role of hepatitis B virus DNA integration in human hepatocarcinogenesis. World J. Gastroenterol. 20, 62366243. doi: 10.3748/wjg.v20.i20.6236

Halgand, B., Desterke, C., Rivière, L., Fallot, G., Sebagh, M., Calderaro, J., et al. (2018). Hepatitis B virus pregenomic RNA in hepatocellular carcinoma: a nosological and prognostic determinant. Hepatology 67, 86-96. doi: 10.1002/ hep. 29463

Hass, M., Hannoun, C., Kalinina, T., Sommer, G., Manegold, C., Günther, S., et al. (2005). Functional analysis of hepatitis B virus reactivating in hepatitis B surface antigen-negative individuals. Hepatology 42, 93-103. doi: 10.1002/hep.20748

$\mathrm{Hu}$, J., Protzer, U., and Siddiqui, A. (2019). Revisiting hepatitis B virus: challenges of curative therapies. J. Virol. 93:e01032-19. doi: 10.1128/JVI.01032-19

Huang, H., Wang, J., Li, W., Chen, R., Chen, X., Zhang, F., et al. (2018). Serum HBV DNA plus RNA shows superiority in reflecting the activity of intrahepatic cccDNA in treatment-naive HBV-infected individuals. J. Clin. Virol. 99-100, 71-78. doi: 10.1016/j.jcv.2017.12.016

Ito, N., Nakashima, K., Sun, S., Ito, M., and Suzuki, T. (2019). Cell type diversity in hepatitis B virus RNA splicing and its regulation. Front. Microbiol. 10:207. doi: $10.3389 /$ fmicb.2019.00207

Jain, S., Chang, T.-T., Chen, S., Boldbaatar, B., Clemens, A., Lin, S. Y., et al. (2015). Comprehensive DNA methylation analysis of hepatitis B virus genome in infected liver tissues. Sci. Rep. 5:10478.

Jeong, J. K., Yoon, G. S., and Ryu, W. S. (2000). Evidence that the 5'-end cap structure is essential for encapsidation of hepatitis B virus pregenomic RNA. J. Virol. 74, 5502-5508. doi: 10.1128/jvi.74.12.5502-5508.2000

Khatun, M., Mondal, R. K., Pal, S., Baidya, A., Bishnu, D., Banerjee, P., et al. (2018). Distinctiveness in virological features and pathogenic potentials of subgenotypes D1, D2, D3 and D5 of Hepatitis B virus. Sci. Rep. 8:8055.

Kim, S. Y., Kyaw, Y. Y., and Cheong, J. (2017). Functional interaction of endoplasmic reticulum stress and hepatitis B virus in the pathogenesis of liver diseases. World J. Gastroenterol. 23, 7657-7665. doi: 10.3748/wjg.v23.i43. 7657

Kitamura, K., Que, L., Shimadu, M., Koura, M., Ishihara, Y., Wakae, K., et al. (2018). Flap endonuclease 1 is involved in cccDNA formation in the hepatitis B virus. PLoS Pathog 14:e1007124. doi: 10.1371/journal.ppat.1007124

Kondo, Y., and Shimosegawa, T. (2015). Significant roles of regulatory T cells and myeloid derived suppressor cells in hepatitis B virus persistent infection and hepatitis B virus-related HCCs. Int. J. Mol. Sci. 16, 3307-3322.

Koniger, C., Wingert, I., Marsmann, M., Rosler, C., Beck, J., and Nassal, M. (2014). Involvement of the host DNA-repair enzyme TDP2 in formation of the covalently closed circular DNA persistence reservoir of hepatitis B viruses. Proc. Natl. Acad. Sci. U.S.A. 111, E4244-E4253.

Kramvis, A. (2014). Genotypes and genetic variability of hepatitis B virus. Intervirology 57, 141-150. doi: 10.1159/000360947

Lam, A. M., Ren, S., Espiritu, C., Kelly, M., Lau, V., Zheng, L., et al. (2017). Hepatitis B virus capsid assembly modulators, but not nucleoside analogs, inhibit the production of extracellular pregenomic RNA and spliced RNA variants. Antimicrob. Agents Chemother. 61, e680-17.

Lan, T., Chang, L., Wu, L., and Yuan, Y. F. (2015). IL-6 plays a crucial role in HBV infection. J. Clin. Transl. Hepatol. 3, 271-276.

Lau, G. K., Piratvisuth, T., Luo, K. X., Marcellin, P., Thongsawat, S., Cooksley, G., et al. (2005). Peginterferon Alfa-2a, lamivudine, and the combination for HBeAg-positive chronic hepatitis B. N. Engl. J. Med. 352, 2682-2695.

Lazar, C., Uta, M., and Branza-Nichita, N. (2014). Modulation of the unfolded protein response by the human hepatitis B virus. Front. Microbiol. 5:433. doi: $10.3389 /$ fmicb. 2014.00433 
Lazarevic, I., Banko, A., Miljanovic, D., and Cupic, M. (2019). Immuneescape hepatitis $\mathrm{B}$ virus mutations associated with viral reactivation upon immunosuppression. Viruses 11:778. doi: 10.3390/v11090778

Le Seyec, J., Chouteau, P., Cannie, I., Guguen-Guillouzo, C., and Gripon, P. (1998). Role of the pre-S2 domain of the large envelope protein in hepatitis B virus assembly and infectivity. J. Virol. 72, 5573-5578. doi: 10.1128/jvi.72.7.55735578.1998

Le Seyec, J., Chouteau, P., Cannie, I., Guguen-Guillouzo, C., and Gripon, P. (1999). Infection process of the hepatitis $\mathrm{B}$ virus depends on the presence of a defined sequence in the pre-S1 domain. J. Virol. 73, 2052-2057. doi: 10.1128/jvi.73.3. 2052-2057.1999

Lee, J. H., Ku, J. L., Park, Y. J., Lee, K. U., Kim, W. H., and Park, J. G. (1999). Establishment and characterization of four human hepatocellular carcinoma cell lines containing hepatitis B virus DNA. World J. Gastroenterol. 5, 289-295. doi: $10.3748 /$ wjg.v5.i4.289

Lee, Y. I., Hwang, J. M., Im, J. H., Lee, Y. I., Kim, N. S., Kim, D. G., et al. (2004). Human hepatitis B virus-X protein alters mitochondrial function and physiology in human liver cells. J. Biol. Chem. 279, 15460-15471. doi: 10.1074/ jbc.m309280200

Li, B., Yan, C., Zhu, J., Chen, X., Fu, Q., Zhang, H., et al. (2020). Anti-PD-1/PD-L1 blockade immunotherapy employed in treating hepatitis B virus infectionrelated advanced hepatocellular carcinoma: a literature review. Front. Immunol. 11:1037.

Li, C., Wang, Y., Wang, S., Wu, B., Hao, J., Fan, H., et al. (2013). Hepatitis B virus mRNA-mediated miR-122 inhibition upregulates PTTG1-binding protein, which promotes hepatocellular carcinoma tumor growth and cell invasion. J. Virol. 87, 2193-2205. doi: 10.1128/jvi.02831-12

Li, W., Han, J., and Wu, H. (2016). Regulatory T-cells promote hepatitis B virus infection and hepatocellular carcinoma progression. Chronic Dis. Transl. Med. $2,67-80$.

Liang, T. J. (2009). Hepatitis B: the virus and disease. Hepatology 49(5 Suppl.), S13-S21.

Lin, C. L., and Kao, J. H. (2015). Hepatitis B virus genotypes and variants. Cold Spring Harb. Perspect. Med. 5:a021436.

Lin, N., Ye, A., Lin, J., Liu, C., Huang, J., Fu, Y., et al. (2020). Diagnostic value of detection of pregenomic RNA in sera of hepatitis B virus-infected patients with different clinical outcomes. J. Clin. Microbiol. 58, e1275-e1219.

Lin, X., Wen, Y., Wan, D., Qian, G., and Gu, J. (2002). Structural and functional analysis of $2.2 \mathrm{~kb}$ spliced variant of hepatitis B virus genomes isolated from liver tissues from hepatocellular carcinoma patients. Zhonghua Shi YanHe Lin Chuang Bing Du Xue Za Zhi 16, 11-15.

Liu, J., Fan, L., Yu, H., Zhang, J., He, Y., Feng, D., et al. (2019). Endoplasmic reticulum stress causes liver cancer cells to release exosomal miR-23a-3p and Up-regulate programmed death ligand 1 expression in macrophages. Hepatology 70, 241-258.

Liu, Y., Jiang, M., Xue, J., Yan, H., and Liang, X. (2019). Serum HBV RNA quantification: useful for monitoring natural history of chronic hepatitis $B$ infection. BMC Gastroenterol 19:53. doi: 10.1186/s12876-019-0966-4

Long, Q., Yan, R., Hu, J., Cai, D., Mitra, B., Kim, E. S., et al. (2017). The role of host DNA ligases in hepadnavirus covalently closed circular DNA formation. PLoS Pathog. 13:e1006784. doi: 10.1371/journal.ppat.1006784

Lucifora, J., Xia, Y., Reisinger, F., Zhang, K., Stadler, D., Cheng, X., et al. (2014). Specific and nonhepatotoxic degradation of nuclear hepatitis B virus cccDNA. Science 343, 1221-1228. doi: 10.1126/science. 1243462

Mason, W. S., Jilbert, A. R., and Summers, J. (2005). Clonal expansion of hepatocytes during chronic woodchuck hepatitis virus infection. Proc. Natl. Acad. Sci. U.S.A. 102, 1139-1144. doi: 10.1073/pnas.04093 32102

Mason, W. S., Liu, C., Aldrich, C. E., Litwin, S., and Yeh, M. M. (2010). Clonal expansion of normal-appearing human hepatocytes during chronic hepatitis $\mathrm{B}$ virus infection. J. Virol. 84, 8308-8315. doi: 10.1128/jvi.00833-10

Mason, W. S., Low, H. C., Xu, C., Aldrich, C. E., Scougall, C. A., Grosse, A., et al. (2009). Detection of clonally expanded hepatocytes in chimpanzees with chronic hepatitis B virus infection. J. Virol. 83, 8396-8408. doi: 10.1128/jvi. 00700-09

McMahon, B. J. (2009). The influence of hepatitis B virus genotype and subgenotype on the natural history of chronic hepatitis B. Hepatol. Int. 3, 334-342. doi: 10.1007/s12072-008-9112-z
Meier, P. J., and Stieger, B. (2002). Bile salt transporters. Annu. Rev. Physiol. 64, 635-661. doi: 10.1146/annurev.physiol.64.082201.100300

Mina, P., Georgiadou, S. P., Rizos, C., Dalekos, G. N., and Rigopoulou, E. I. (2010). Prevalence of occult hepatitis B virus infection in haemodialysis patients from central Greece. World J. Gastroenterol. 16, 225-231.

Mondal, R. K., Khatun, M., Banerjee, P., Ghosh, A., Sarkar, S., Santra, A., et al. (2017). Synergistic impact of mutations in hepatitis B virus genome contribute to its occult phenotype in chronic hepatitis C virus carriers. Sci. Rep. 7:9653.

Nassal, M. (1992). The arginine-rich domain of the hepatitis B virus core protein is required for pregenome encapsidation and productive viral positive-strand DNA synthesis but not for virus assembly. J. Virol. 66, 4107-4116. doi: 10.1128/ jvi.66.7.4107-4116.1992

Nassal, M. (2008). Hepatitis B viruses: reverse transcription a different way. Virus Res. 134, 235-249. doi: 10.1016/j.virusres.2007.12.024

Niederau, C., Heintges, T., Lange, S., Goldmann, G., Niederau, C. M., Mohr, L., et al. (1996). Long-term follow-up of HBeAg-positive patients treated with interferon alfa for chronic hepatitis B. N. Engl. J. Med. 334, 1422-1427. doi: 10.1056/nejm199605303342202

Osiowy, C., Giles, E., Tanaka, Y., Mizokami, M., and Minuk, G. Y. (2006). Molecular evolution of hepatitis B virus over 25 years. J. Virol. 80, 10307-10314. doi: 10.1128/jvi.00996-06

Ou, J. H., and Rutter, W. J. (1987). Regulation of secretion of the hepatitis B virus major surface antigen by the preS-1 protein. J. Virol. 61, 782-786. doi: 10.1128/jvi.61.3.782-786.1987

Pal, S., Nandi, M., Dey, D., Chakraborty, B. C., Shil, A., Ghosh, S., et al. (2019). Myeloid-derived suppressor cells induce regulatory $\mathrm{T}$ cells in chronically HBV infected patients with high levels of hepatitis B surface antigen and persist after antiviral therapy. Aliment Pharmacol. Ther. 49, 1346-1359.

Pan, J., Xu, J., Luo, H., Tan, N., Kang, Q., Chen, H., et al. (2021). Factors and virological significance of hepatitis B virus pregenomic RNA status after 5 years of antiviral therapy. Int. J. Infect. Dis. 105, 418-423. doi: 10.1016/j.ijid.2021.02. 116

Park, N. H., Song, I. H., and Chung, Y. H. (2007). Molecular pathogenesis of hepatitis-B-virus-associated hepatocellular carcinoma. Gut Liver 1, 101-117. doi: $10.5009 /$ gnl.2007.1.2.101

Patient, R., Hourioux, C., and Roingeard, P. (2009). Morphogenesis of hepatitis B virus and its subviral envelope particles. Cell Microbiol. 11, 1561-1570. doi: 10.1111/j.1462-5822.2009.01363.x

Pawlotsky, J. M. (2005). The concept of hepatitis B virus mutant escape. J. Clin. Virol. 34, S125-S129.

Podlaha, O., Wu, G., Downie, B., Ramamurthy, R., Gaggar, A., Subramanian, M., et al. (2019). Genomic modeling of hepatitis B virus integration frequency in the human genome. PLoS One 14:e0220376. doi: 10.1371/journal.pone.0220376

Pol, J. G., Lekbaby, B., Redelsperger, F., Klamer, S., Mandouri, Y., Ahodantin, J., et al. (2015). Alternative splicing-regulated protein of hepatitis B virus hacks the TNF-alpha-stimulated signaling pathways and limits the extent of liver inflammation. FASEB J. 29, 1879-1889. doi: 10.1096/fj.14-258715

Pollicino, T., Cacciola, I., Saffioti, F., and Raimondo, G. (2014). Hepatitis B virus PreS/S gene variants: pathobiology and clinical implications. J. Hepatol. 61, 408-417. doi: 10.1016/j.jhep.2014.04.041

Qi, Y., Gao, Z., Xu, G., Peng, B., Liu, C., Yan, H., et al. (2016). DNA polymerase kappa is a key cellular factor for the formation of covalently closed circular DNA of hepatitis B virus. PLoS Pathog 12:e1005893. doi: 10.1371/journal.ppat. 1005893

Quarleri, J. (2014). Core promoter: a critical region where the hepatitis B virus makes decisions. World J. Gastroenterol. 20, 425-435. doi: 10.3748/wjg.v20.i2. 425

Ramanan, V., Shlomai, A., Cox, D. B., Schwartz, R. E., Michailidis, E., Bhatta, A., et al. (2015). CRISPR/Cas9 cleavage of viral DNA efficiently suppresses hepatitis B virus. Sci. Rep. 5:10833.

Riviere, L., Gerossier, L., Ducroux, A., Dion, S., Deng, Q., Michel, M. L., et al. (2015). HBx relieves chromatin-mediated transcriptional repression of hepatitis B viral cccDNA involving SETDB1 histone methyltransferase. J. Hepatol. 63:1093-102.

Rosmorduc, O., Petit, M. A., Pol, S., Capel, F., Bortolotti, F., Berthelot, P., et al. (1995). In vivo and in vitro expression of defective hepatitis B virus particles generated by spliced hepatitis B virus RNA. Hepatology 22, 10-19. doi: 10.1016/ 0270-9139(95)90346- 1 
Salerno, D., Chiodo, L., Alfano, V., Floriot, O., Cottone, G., Paturel, A., et al. (2020). Hepatitis B protein HBx binds the DLEU2 IncRNA to sustain cccDNA and host cancer-related gene transcription. Gut 69, 2016-2024.

Sanchez-Tapias, J. M., Costa, J., Mas, A., Bruguera, M., and Rodés, J. (2002). Influence of hepatitis B virus genotype on the long-term outcome of chronic hepatitis B in western patients. Gastroenterology 123, 1848-1856. doi: 10.1053/ gast.2002.37041

Selzer, L., and Zlotnick, A. (2015). Assembly and Release of Hepatitis B Virus. Cold Spring Harb. Perspect. Med. 5:a021394. doi: 10.1101/cshperspect.a021394

Shi, Y., Du, L., Lv, D., Li, H., Shang, J., Lu, J., et al. (2019). Exosomal interferoninduced transmembrane protein 2 transmitted to dendritic cells inhibits interferon alpha pathway activation and blocks anti-hepatitis B virus efficacy of exogenous interferon alpha. Hepatology 69, 2396-2413.

Simmonds, P., and Midgley, S. (2005). Recombination in the genesis and evolution of hepatitis B virus genotypes. J. Virol. 79, 15467-15476. doi: 10.1128/jvi.79.24. 15467-15476.2005

Somiya, M., Liu, Q., Yoshimoto, N., Iijima, M., Tatematsu, K., Nakai, T., et al. (2016). Cellular uptake of hepatitis B virus envelope $\mathrm{L}$ particles is independent of sodium taurocholate cotransporting polypeptide, but dependent on heparan sulfate proteoglycan. Virology 497, 23-32. doi: 10.1016/j.virol.2016.06.024

Sommer, G., van Bömmel, F., and Will, H. (2000). Genotype-specific synthesis and secretion of spliced hepatitis B virus genomes in hepatoma cells. Virology 271, 371-381. doi: 10.1006/viro.2000.0331

Soussan, P., Tuveri, R., Nalpas, B., Garreau, F., Zavala, F., Masson, A., et al. (2003). The expression of hepatitis B spliced protein (HBSP) encoded by a spliced hepatitis B virus RNA is associated with viral replication and liver fibrosis. J. Hepatol. 38, 343-348. doi: 10.1016/s0168-8278(02)00422-1

Su, I. J., Wang, H. C., Wu, H. C., and Huang, W. Y. (2008). Ground glass hepatocytes contain pre-S mutants and represent preneoplastic lesions in chronic hepatitis B virus infection. J. Gastroenterol. Hepatol. 23, 1169-1174. doi: 10.1111/j.1440-1746.2008.05348.x

Su, T. S., Lai, C. J., Huang, J. L., Lin, L. H., Yauk, Y. K., Chang, C. M., et al. (1989). Hepatitis B virus transcript produced by RNA splicing. J. Virol. 63, 4011-4018. doi: 10.1128/jvi.63.9.4011-4018.1989

Summers, J., Smith, P. M., Huang, M. J., and Yu, S. (1991). Morphogenetic and regulatory effects of mutations in the envelope proteins of an avian hepadnavirus. J. Virol. 65, 1310-1317. doi: 10.1128/jvi.65.3.1310-1317.1991

Takata, A., Otsuka, M., Ohno, M., Kishikawa, T., Yoshikawa, T., Koike, K., et al. (2016). Mutual antagonism between hepatitis B viral mRNA and host microRNA let-7. Sci. Rep. 6:23237.

Tan, A., Koh, S., and Bertoletti, A. (2015). Immune response in hepatitis B virus infection. Cold Spring Harb. Perspect. Med. 5:a021428.

Tang, L., Sheraz, M., McGrane, M., Chang, J., and Guo, J. T. (2019). DNA polymerase alpha is essential for intracellular amplification of hepatitis B virus covalently closed circular DNA. PLoS Pathog 15:e1007742. doi: 10.1371/journal. ppat. 1007742

Terré, S., Petit, M. A., and Bréchot, C. (1991). Defective hepatitis B virus particles are generated by packaging and reverse transcription of spliced viral RNAs in vivo. J. Virol. 65, 5539-5543. doi: 10.1128/jvi.65.10.5539-5543. 1991

Thukar, V., Guptan, R. C., Kazim, S. N., Malhotra, V., and Sarin, S. K. (2002). Profile, spectrum and significance of HBV genotypes in chronic liver disease patients in the Indian subcontinent. J. Gastroenterol. Hepatol. 17, 165-170. doi: 10.1046/j.1440-1746.2002.02605.x

Torresi, J., Earnest-Silveira, L., Civitico, G., Walters, T. E., Lewin, S. R., Fyfe, J., et al. (2002). Restoration of replication phenotype of lamivudine resistant hepatitis B virus mutants by compensatory changes in the "fingers" subdomain of the viral polymerase selected as a consequence of mutations in the overlapping $\mathrm{S}$ gene. Virology 299, 88-99. doi: 10.1006/viro.2002.1448

Trehanpati, N., Hissar, S., Shrivastav, S., and Sarin, S. K. (2013). Immunological mechanisms of hepatitis B virus persistence in newborns. Indian J. Med. Res. 138, 700-710.

Tu, J. F., Ding, Y. H., Ying, X. H., Wu, F. Z., Zhou, X. M., Zhang, D. K., et al. (2016). Regulatory T cells, especially $\mathrm{ICOS}^{+} \mathrm{FOXP}^{+}{ }^{+}$regulatory $\mathrm{T}$ cells, are increased in the hepatocellular carcinoma microenvironment and predict reduced survival. Sci. Rep. 6:35056.

Trujillo, J. A., Sweis, R. F., Bao, R., Luke, J. J. (2018). T cell-inflamed versus Non$\mathrm{T}$ cell-inflamed tumors: a conceptual framework for cancer immunotherapy drug development and combination therapy selection. Cancer Immunol. Res. $6,990-1000$.

Twist, E. M., Clark, H. F., Aden, D. P., Knowles, B. B., and Plotkin, S. A. (1981). Integration pattern of hepatitis B virus DNA sequences in human hepatoma cell lines. J. Virol. 37, 239-243. doi: 10.1128/jvi.37.1.239-243.1 981

Valenzuela, P., Gray, P., Quiroga, M., Zaldivar, J., Goodman, H. M., and Rutter, W. J. (1979). Nucleotide sequence of the gene coding for the major protein of hepatitis B virus surface antigen. Nature 280, 815-819. doi: 10.1038/280815a0

Velay, A., Jeulin, H., Eschlimann, M., Malvé, B., Goehringer, F., Bensenane, M., et al. (2016). Characterization of hepatitis B virus surface antigen variability and impact on HBs antigen clearance under nucleos(t)ide analogue therapy. J. Viral. Hepat. 23, 387-398. doi: 10.1111/jvh.12498

Wai, C. T., Fontana, R. J., Polson, J., Hussain, M., Shakil, A. P., Han, S. H., et al. (2005). Clinical outcome and virological characteristics of hepatitis B-related acute liver failure in the United States. J. Viral. Hepat. 12, 192-198. doi: 10. 1111/j.1365-2893.2005.00581.x

Wang, H. C., Wu, H. C., Chen, C. F., Fausto, N., Lei, H. Y., and Su, I. J. (2003). Different types of ground glass hepatocytes in chronic hepatitis $\mathrm{B}$ virus infection contain specific pre-S mutants that may induce endoplasmic reticulum stress. Am. J. Pathol. 163, 2441-2449. doi: 10.1016/s0002-9440(10)635 99-7

Wang, H. Y., Chien, M. H., Huang, H. P., Chang, H. C., Wu, C. C., Chen, P. J., et al. (2010). Distinct hepatitis B virus dynamics in the immunotolerant and early immunoclearance phases. J. Virol. 84, 3454-3463. doi: 10.1128/jvi.02164-09

Wang, J., Yu, Y., Li, G., Shen, C., Meng, Z., Zheng, J., et al. (2018a). Relationship between serum HBV-RNA levels and intrahepatic viral as well as histologic activity markers in entecavir-treated patients. J Hepatol 68, 16-24. doi: 10.1016/ j.jhep.2017.08.021

Wang, J., Yu, Y., Li, G., Shen, C., Li, J., Chen, S., et al. (2018b). Natural history of serum HBV-RNA in chronic HBV infection. J Viral Hepat 25, 1038-1047. doi: $10.1111 /$ jvh. 12908

Wang, J., Zhang, P., Zeng, J., Du, P., Zheng, X., Ye, X., et al. (2020). Occurrence of occult hepatitis B virus infection associated with envelope protein mutations according to anti-HBs carriage in blood donors. Int. J. Infect. Dis. 92, 38-45. doi: 10.1016/j.ijid.2019.12.026

Wang, Y., Jiang, L., Ji, X., Yang, B., Zhang, Y., Fu, X. D., et al. (2013). Hepatitis $B$ viral RNA directly mediates down-regulation of the tumor suppressor microRNA miR-15a/miR-16-1 in hepatocytes. J. Biol. Chem. 288, 18484-18493. doi: $10.1074 /$ jbc.m113.458158

Weber, B. (2005). Genetic variability of the S gene of hepatitis B virus: clinical and diagnostic impact. J. Clin. Virol. 32, 102-112. doi: 10.1016/j.jcv.2004.10.008

Weber, M., Bronsema, V., Bartos, H., Bosserhoff, A., Bartenschlager, R., and Schaller, H. (1994). Hepadnavirus P protein utilizes a tyrosine residue in the TP domain to prime reverse transcription. J. Virol. 68, 2994-2999. doi: 10.1128/jvi. 68.5.2994-2999.1994

WHO (2020). World's Hepatitis Day. Geneva: WHO

Will, H., Reiser, W., Weimer, T., Pfaff, E., Buscher, M., Sprengel, R., et al. (1987). Replication strategy of human hepatitis B virus. J. Virol. 61, 904-911. doi: 10.1128/jvi.61.3.904-911.1987

Wu, C., Zhang, X., Tian, Y., Song, J., Yang, D., Roggendorf, M., et al. (2010). Biological significance of amino acid substitutions in hepatitis B surface antigen (HBsAg) for glycosylation, secretion, antigenicity and immunogenicity of HBsAg and hepatitis B virus replication. J. Gen. Virol. 91(Pt. 2), 483-492. doi: 10.1099/vir.0.012740-0

Wu, H. L., Chen, P. J., Tu, S. J., Lin, M. H., Lai, M. Y., Chen, D. S., et al. (1991). Characterization and genetic analysis of alternatively spliced transcripts of hepatitis B virus in infected human liver tissues and transfected HepG2cells. J. Virol. 65, 1680-1686. doi: 10.1128/jvi.65.4.1680-1686.1991

Wu, S. X., Chen, W. N., Jing, Z. T., Liu, W., Lin, X. J., and Lin, X. (2018). Hepatitis B spliced protein (HBSP) suppresses fas-mediated hepatocyte Apoptosis via activation of PI3K/Akt signaling. J. Virol. 92:e1273-18.

Xia, Y., and Guo, H. (2020). Hepatitis B virus cccDNA: formation, regulation and therapeutic potential. Antiviral. Res. 180:104824. doi: 10.1016/j.antiviral.2020. 104824

Xu, Z., Jensen, G., and Yen, T. S. (1997). Activation of hepatitis B virus S promoter by the viral large surface protein via induction of stress in the endoplasmic reticulum. J. Virol. 71, 7387-7392. doi: 10.1128/jvi.71.10.7387-7392.1997 
Yaginuma, K., Nakamura, I., Takada, S., and Koike, K. (1993). A transcription initiation site for the hepatitis $\mathrm{B}$ virus $\mathrm{X}$ gene is directed by the promoter binding protein. J. Virol. 67, 2559-2565. doi: 10.1128/jvi.67.5.2559-2565.1993

Yan, H., Zhong, G., Xu, G., He, W., Jing, Z., Gao, Z., et al. (2012). Sodium taurocholate cotransporting polypeptide is a functional receptor for human hepatitis B and D virus. eLife. 13:e00049.

Yang, Y. C., Chen, Y. H., Kao, J. H., Ching, C., Liu, I. J., Wang, C. C., et al. (2020). Permanent inactivation of HBV genomes by CRISPR/Cas9-mediated non-cleavage base editing. Mol. Ther. Nucleic Acids 20, 480-490. doi: 10.1016/ j.omtn.2020.03.005

Yang, P., Markowitz, G. J., and Wang, X. F. (2014). The hepatitis B virus-associated tumor microenvironment in hepatocellular carcinoma. Nat. Sci. Rev. 1, 396412.

Yen, T. T., Yang, A., Chiu, W. T., Li, T. N., Wang, L. H., Wu, Y. H., et al. (2016). Hepatitis B virus PreS2-mutant large surface antigen activates storeoperated calcium entry and promotes chromosome instability. Oncotarget 7, 23346-23360. doi: 10.18632/oncotarget.8109

Zhang, X., Zhang, H., and Ye, L. (2006). Effects of hepatitis B virus X protein on the development of liver cancer. J. Lab Clin. Med. 147, 58-66. doi: 10.1016/j. lab.2005.10.003

Zhang, Y., Li, C., Zhang, Y., Zhu, H., Kang, Y., Liu, H., et al. (2013). Comparative analysis of CpG islands among HBV genotypes. PLoS One 8:e56711. doi: 10. 1371/journal.pone.0056711

Zhang, Y., Mao, R., Yan, R., Cai, D., Zhang, Y., Zhu, H., et al. (2014). Transcription of hepatitis B virus covalently closed circular DNA is regulated by CpG methylation during chronic infection. PLoS One 9:e110442. doi: 10.1371/ journal.pone.0110442

Zhao, K., Liu, A., and Xia, Y. (2020). Insights into hepatitis B virus DNA integration-55 years after virus discovery. Innovation 1:100034. doi: 10.1016/ j.xinn.2020.100034

Zhao, L. H., Liu, X., Yan, H. X., Li, W. Y., Zeng, X., Yang, Y., et al. (2016). Genomic and oncogenic preference of HBV integration in hepatocellular carcinoma [published correction appears in Nat Commun. 2016 Nov 08;7:13591. Lee, TP [corrected to Lee, TL]]. Nat. Commun. 7:12992.

Zheng, X., Weinberger, K. M., Gehrke, R., Isogawa, M., Hilken, G., Kemper, T., et al. (2004). Mutant hepatitis B virus surface antigens (HBsAg) are immunogenic but may have a changed specificity. Virology 329, 454-464. doi: 10.1016/j.virol. 2004.08.033

Zhong, H., Xibing, G., Yaping, D., Zheng, W., Decai, F., Xiaoye, G., et al. (2016). Interleukin-7 in patients with chronic hepatitis B may have effect on T follicular helper cells and specific cellular immunity. Hepat Mon. 16:e36068.

Zhou, Y., and Holmes, E. C. (2007). Bayesian estimates of the evolutionary rate and age of hepatitis B virus. J. Mol. Evol. 65, 197-205. doi: 10.1007/s00239007-0054-1

Zhu, A., Liao, X., Li, S., Zhao, H., Chen, L., Xu, M., et al. (2019). HBV cccDNA and its potential as a therapeutic target. J. Clin. Transl. Hepatol. 7, $258-262$.

Conflict of Interest: The authors declare that the research was conducted in the absence of any commercial or financial relationships that could be construed as a potential conflict of interest.

Publisher's Note: All claims expressed in this article are solely those of the authors and do not necessarily represent those of their affiliated organizations, or those of the publisher, the editors and the reviewers. Any product that may be evaluated in this article, or claim that may be made by its manufacturer, is not guaranteed or endorsed by the publisher.

Copyright (c) 2021 Ghosh, Chakraborty and Banerjee. This is an open-access article distributed under the terms of the Creative Commons Attribution License (CC BY). The use, distribution or reproduction in other forums is permitted, provided the original author(s) and the copyright owner(s) are credited and that the original publication in this journal is cited, in accordance with accepted academic practice. No use, distribution or reproduction is permitted which does not comply with these terms. 